\title{
STRATEGY COPING DAN PENDAPATAN NELAYAN: SEBUAH KAJIAN EMPIRIK
}

\section{Coping Strategy and Fisher's Income: An Empirical Study}

\author{
*Dini Yuniarti dan Lestari Sukarniati
}

\author{
Universitas Ahmad Dahlan \\ JI. Kapas No.9, Semaki, Kec. Umbulharjo, Daerah Istimewa Yogyakarta 55166, Indonesia \\ Diterima tanggal: 22 Februari 2020 Diterima setelah perbaikan: 22 Maret 2021 \\ Disetujui terbit: 25 Juni 2021
}

\begin{abstract}
ABSTRAK
Perubahan iklim menyebabkan nelayan menghadapi kesulitan ekonomi, untuk mengatasi hal tersebut nelayan melakukan strategi coping. Studi ini bermaksud 1) Mengetahui strategi coping apa saja yang dilakukan nelayan; 2) Mengkaji pengaruh strategi coping terhadap pendapatan nelayan; 3) Mengetahui pengaruh faktor sosio ekonomi dan demografi terhadap pendapatan nelayan. Metode penelitian menggunakan pendekatan kuantitatif, dengan tingkat eksplanasi deskriptif dan asosiatif. Data yang digunakan merupakan data primer berupa data cross section. Responden merupakan nelayan di Kabupaten Bantul dan Kabupaten Gunungkidul. Sampel penelitian sebanyak 99 nelayan. Pengumpulan data menggunakan metoda wawancara dengan menggunakan kuesioner. Alat analisis yang digunakan statistik deskriptif dan regresi berganda. Hasil penelitian menunjukkan 1) Strategi coping saat tidak melaut terdiri dari tiga strategi utama yaitu pasif, aktif dan jaringan. Strategi pasif dengan menghemat pengeluaran dan mengkonsumsi makanan yang terjangkau. Strategi aktif menjaga pemasukan nelayan dengan mencari pekerjaan lain, menjual aset dan migrasi, sedangkan strategi jaringan dengan meminjam uang kepada kerabat dan lembaga keuangan. 2) Strategi coping berpengaruh negatif terhadap pendapatan nelayan. 3) Faktor sosio ekonomi dan demografi yang memiliki pengaruh positif terhadap pendapatan nelayan adalah pengalaman melaut dan kepemilikan perahu, pendidikan nelayan, usia nelayan dan jarak tidak berpengaruh terhadap pendapatan nelayan. Pemerintah perlu meningkatkan kemampuan nelayan melalui kepemilikan perahu dan meningkatkan keterampilan melaut untuk meningkatkan pendapatan.
\end{abstract}

Kata Kunci: perubahan iklim; strategi coping; pendapatan; nelayan; sosio ekonomi

\begin{abstract}
Climate change causes fishermen to face economic difficulties. To overcome this, fishermen carry out coping strategies. This study is intended to 1) Identify the coping strategies of fishers; 2) Analyze the effect of coping strategies on fishers'income; 3) Analyze the influence of socioeconomic and demographic factors on fishers' income. The study used quantitative method with descriptive and associative explanation. It is a cross-sectional study of primary data that were collected form 99 respondents of the fishers in Bantul Regency and Gunungkidul Regency. Data were collected by questionnaires interviews. The analytical tool used is descriptive statistics and multiple regression. The results showed that 1) The coping strategies applied when fishers do not go fishing consist of three main strategies, namely: passive, active and networking. Passive strategy is managing expenses and consuming affordable food. Active strategy is protecting fishers' income by finding other jobs, migration and selling assets. Meanwhile, networking strategies is borrowing money from relatives and financial institutions. 2) Coping strategy tend to decrease fishers's income. 3) Socio-economic and demographic factors that have positive influence on fishers's income are fishing experience and boat ownership. Fishers education, age and distance do not affect the fishers' income. It is necessary to improve fishers' capability with boat ownership and fishing skill to increase fishers's income.
\end{abstract}

Keywords: cllimate change; coping strategy; income; fishers; socio-economic 


\section{PENDAHULUAN}

Kelompok masyarakat yang rentan dan dekat dengan kemiskinan adalah nelayan yang biasanya berada di daerah pesisir. Dalam RJPMN 2015-2019 nelayan dimasukan sebagai kelompok rumah tangga yang diperkirakan berada pada 40 persen penduduk berpendapatan terbawah (Badan Perencanaan Pembangunan Nasional, 2014). Hal ini disebabkan nelayan menggantungkan hidupnya dari sumberdaya laut dan pantai yang sangat bergantung pada musim. Selain itu menurut Retnowati (2011) hal ini dikarenakan keterbatasan modal, skill, sistem bagi hasil perikanan dan perdagangan atau pelelangan ikan yang belum transparan, serta budaya kerja yang masih bersifat konvensional. Menurut Imron (2003), kemiskinan tersebut tidak hanya dalam bentuk ekonomi, melainkan juga dalam dimensi sosial, budaya bahkan politik. Salah satu penyebab munculnya kemiskinan adalah keterbatasan teknologi penangkapan. Selain itu menurut Widodo (2011) kemiskinan bersumber dari rendahnya akses terhadap modal, utamanya modal finansial.

Selain faktor di atas, usaha nelayan yang memiliki sifat musiman dan sangat tergantung kepada kondisi alam, menyebabkan nelayan tidak memiliki pendapatan yang tetap dan menghadapi kerentanan dalam ekonominya. Salah satu penyebab kerentanan yang menjadi perhatian dunia saat ini adalah perubahan iklim yang sering terjadi. Perubahan iklim menyebabkan nelayan menghadapi masalah baik sosial maupun ekonomi. Secara sosial nelayan sulit menentukan musim, jarak tempuh menjadi lebih jauh dan berkurangnya sumber daya perikanan. Secara ekonomi perubahan iklim menyebabkan nelayan lebih rentan terhadap kemiskinan (Ulfa, 2018). Selain itu perubahan iklim meningkatkan resiko melaut, bertambah nya biaya melaut, kurang efektifnya alat tangkap dan sulitnya menentukan wilayah tangkap (Dewiyanti, Ma'ruf \& Indriyani, 2019; Patriana \& Satria, 2013)

Nelayan menghadapi kerentanan ekonomi tersebut melakukan berbagai upaya atau strategi coping untuk tetap mempertahankan nafkah. Menurut Maryam (2017) perilaku coping merupakan transaksi yang dilakukan individu untuk mengatasi berbagai tuntutan (internal dan eksternal) sebagai sesuatu yang membebani dan mengganggu kelangsungan hidupnya.
Beberapa studi menunjukkan nelayan telah melakukan berbagai strategi coping antara lain berupa strategi struktural, ekonomi, sosial dan budaya (Lailiyah et al., 2018; Setiawan, 2016). Strategi lainnya meliputi nafkah ganda (Wibowo \& Satria, 2015; Widodo, 2011; Akbar \& Huda, 2017; Susilo et al., 2021), melibatkan keluarga (Widodo, 2011; Prihatin, 2017), strategi sosial memanfaatkan ikatan kekerabatan (Widodo, 2011) menjalin hubungan baik dengan pemilik perahu motor atau pemberi modal awal sebelum melaut, menghemat pengeluaran terutama ketika datangnya masa paceklik (Prihatin, 2017) dan migrasi (Widodo, 2011). Strategi lain yang dilakukan adalah dengan mengembangkan budidaya rumput laut (Zamroni \& Yamao, 2011), melakukan perubahan alat tangkap ikan (Casmiwati et al., 2019; Setiawan, 2016), meminjam kepada kerabat atau tetangga (Casmiwati et al., 2019).

Nelayan telah melakukan beragam strategi coping untuk mempertahankan nafkah keluarga. Apakah strategi-strategi coping tersebut mempengaruhi nafkah atau pendapatan nelayan. Studi ini bertujuan untuk 1) Mengetahui strategi coping apa saja yang dilakukan nelayan; 2) Mengkaji pengaruh strategi coping terhadap pendapatan nelayan; 3) Mengetahui pengaruh faktor sosio ekonomi dan demografi terhadap pendapatan nelayan.

\section{METODOLOGI}

Penelitian ini menggunakan pendekatan kuantitatif, yang menguji hubungan antar variabel. Variabel-variabel tersebut dapat diukur, sehingga data tersebut dapat dianalisis menggunakan prosedur statistik (Creswell, 2013). Alat analisis yang digunakan adalah statistik deskriptif dan regresi berganda. Penjelasan mengenai lokasi, waktu, sampel, jenis dan metoda pengambilan data, persamaan statistik serta alat analisis akan dijelaskan di bawah ini.

\section{Lokasi dan Waktu Penelitian}

Lokasi penelitian dilakukan di pantai Kabupaten Bantul dan Gunungkidul Daerah Istimewa Yogyakarta. Penelitian dilakukan di Daerah Istimewa Yogyakarta karena memiliki karakteristik yang menarik untuk dikaji. Pertama, menurut Suadi (2001) nelayan pantai selatan DIY merupakan masyarakat petani yang kemudian 
beralih ke aktivitas ke nelayan. Hal ini merupakan pola strategi adaptasi karena adanya keterbatasan lahan dan pekerjaan. Kedua, jumlah nelayan di Daerah Istimewa Yogyakarta paling sedikit dibandingkan provinsi lain yaitu pada tahun 2016 sebanyak 1513 nelayan (Statistik Sumber Daya Laut dan Pesisir, Badan Pusat Statistik, 2018). Tabel 1 menunjukkan jumlah nelayan di provinsi-provinsi Indonesia, dimana Daerah Istimewa Yogyakarta merupakan provinsi dengan jumlah nelayan yang paling sedikit.

Untuk lokasi di Kabupaten Bantul meliputi lima pantai, yaitu Pantai Depok, Pantai Samas, Pantai Pandan Simo, Pantai Kwaru dan Pantai
Goa Cemara. Adapun lokasi penelitian di Kabupaten Gunungkidul yaitu Pantai Baron dan Pantai Drini. Pelaksanaan penelitian pada bulan Juli dan Agustus 2019. Pemilihan lokasi di Daerah Istimewa Yogyakarta karena kondisi fisik pantai dengan perairan dangkal yang tidak terlalu lebar serta adanya gelombang besar (pada musim tenggara pada bulan Juni sampai September) yang sering penghambat upaya perluasan daerah penangkapan (Suadi, 2001). Kondisi ini diperkiraan akan mendorong nelayan melakukan strategi coping. Selanjutnya pemilihan pantai di Kabupaten Bantul dan Kabupaten Gunungkidul karena keduanya memiliki perkembangan perikanan tangkap yang berbeda. Menurut Suadi (2001) Pantai Baron

Tabel 1. Jumlah Nelayan di Laut Menurut Provinsi, 2012-2016

Table 1. Number of Marine Fishers By Province, at 2012-2016.

\begin{tabular}{|c|c|c|c|c|c|}
\hline Provinsi/Province & 2012 & 2013 & 2014 & 2015 & 2016 \\
\hline Aceh & 64,968 & 70,771 & 70,771 & 73,122 & 73,122 \\
\hline Sumatera Utara & 183,751 & 129,160 & 123,998 & 197,016 & 219,527 \\
\hline Sumatera Barat & 38,387 & 40,378 & 41,425 & 42,061 & 40,359 \\
\hline Riau & 48,111 & 42,800 & 30,534 & 53,610 & 42,793 \\
\hline Jambi & 15,506 & 49,191 & 8,441 & 12,864 & 14,744 \\
\hline Sumatera Selatan & 33,363 & 33,818 & 33,377 & 18,726 & 18,650 \\
\hline Bengkulu & 19,266 & 20,475 & 20,924 & 21,097 & 21,097 \\
\hline Lampung & 36,370 & 36,405 & 28,562 & 30,370 & 33,929 \\
\hline $\begin{array}{l}\text { Kepulauan Bangka } \\
\text { Belitung }\end{array}$ & 81,205 & 39,399 & 34,208 & 36,298 & 46,834 \\
\hline Kepulauan Riau & 113,297 & 112,554 & 113,904 & 85,618 & 85,618 \\
\hline DKI Jakarta & 61,813 & 28,268 & 27,396 & 27,323 & 2,863 \\
\hline Jawa Barat & 98,110 & 101,042 & 104,088 & 98,851 & 74,949 \\
\hline Jawa Tengah & 100,030 & 102,963 & 99,290 & 154,511 & 171,064 \\
\hline DI Yogyakarta & 3,338 & 2,871 & 2,735 & 731 & 1,513 \\
\hline Jawa Timur & 226,303 & 210,649 & 227,888 & 233,117 & 224,007 \\
\hline Banten & 27,649 & 26,765 & 39,802 & 30,336 & 52,178 \\
\hline Bali & 54,237 & 50,888 & 29,568 & 49,471 & 47,324 \\
\hline Nusa Tenggara Barat & 71,250 & 40,115 & 64,631 & 65,778 & 64,953 \\
\hline Nusa Tenggara Timur & 44,260 & 47,927 & 52,210 & 75,850 & 75,850 \\
\hline Kalimantan Barat & 57,721 & 56,998 & 61,858 & 61,904 & 40,046 \\
\hline Kalimantan Tengah & 27,161 & 21,125 & 31,711 & 65,810 & 19,659 \\
\hline Kalimantan Selatan & 52,192 & 53,195 & 54,831 & 49,542 & 19,118 \\
\hline Kalimantan Timur & 137,041 & 42,491 & 45,533 & 33,345 & 33,345 \\
\hline Kalimantan Utara & -1 & -1 & -1 & 7,761 & 7,810 \\
\hline Sulawesi Utara & 65,861 & 115,730 & 128,664 & 68,236 & 129,231 \\
\hline Sulawesi Tengah & 125,202 & 149,217 & 94,970 & 44,874 & 69,476 \\
\hline Sulawesi Selatan & 108,988 & 122,177 & 114,005 & 213,839 & 154,701 \\
\hline Sulawesi Tenggara & 79,421 & 77,044 & 107,132 & 70,978 & 90,674 \\
\hline Gorontalo & 18,981 & 44,734 & 57,533 & 19,348 & 58,463 \\
\hline Sulawesi Barat & 50,402 & 19,013 & 19,013 & 57,318 & 19,548 \\
\hline Maluku & 124,894 & 119,645 & 208,448 & 94,375 & 117,395 \\
\hline Maluku Utara & 16,607 & 17,235 & 18,778 & 19,056 & 20,286 \\
\hline Papua Barat & 30,865 & 39,954 & 43,031 & 81,025 & 81,025 \\
\hline Papua & 61,838 & 99,972 & 70,936 & 80,978 & 93,708 \\
\hline Indonesia & $2,278,388$ & $2,164,969$ & $2,210,195$ & $2,275,139$ & $2,265,859$ \\
\hline
\end{tabular}

Badan Pusat Statistik, Statistik Sumber Daya Laut dan Pesisir. (2018) 
merupakan pantai yang paling awal mengalami perkembangan perikanan tangkap pada akhir tahun 1970-an atau awal tahun 1980-an, sehingga diperkirakan memiliki pengalaman yang lebih lama dalam menghadapi kerentanan dibandingkan dengan nelayan di Pantai Bantul yang berkembang setelahnya. Adanya perbedaan perkembangan ini diduga akan memberikan perbedaan dalam strategi coping di kedua lokasi.

\section{Jenis dan Metode Pengambilan Data}

Jenis data yang digunakan dalam penelitian berupa data kuantitatif dan data kualitatif. Data kuantitatif berupa data pendapatan, usia, pengalaman melaut, jarak, dan lama sekolah. Adapun data kualitatif berupa strategi coping dan kepemilikan perahu. Sumber data merupakan data primer berupa cross section yang diperoleh melalui wawancara dengan menggunakan kuisioner.

Populasi nelayan di DIY berdasarkan data Statistik Sumber Daya Laut dan Pesisir, Badan Pusat Statistik (2018) pada tahun 2016 sebanyak 1513 nelayan. Penentuan jumlah sampel menggunakan metoda Slovin dengan margin error $10 \%$. Jumlah sampel dalam penelitian ini sebanyak 99 nelayan, terdiri dari 50 nelayan di Kabupaten Bantul dan 49 di Kabupaten Gunungkidul. Teknik sampling menggunakan non-probability sampling dengan metoda convenience.

\section{Metode Analisis}

Variabel startegi coping dalam penelitian ini mengacu kepada konsep startegi coping dari Maryam (2017) bahwa perilaku coping merupakan transaksi yang dipilih oleh individu dalam mengatasi hal-hal yang akan mengganggu kelangsungan hidupnya. Dalam hal ini strategi coping yang digunakan adalah diversifikasi kegiatan ekonomi dengan mencari pekerjaan lain (Wibowo \& Satria, 21015; Widodo, 2011;Akbar \& Huda, 2017). Untuk menganalisis pengaruh strategi coping, jarak melaut, pengalaman melaut, kepemilikan perahu, lama sekolah dan usia nelayan terhadap pendapatan nelayan menggunakan regresi berganda dengan metoda Ordinary Least Square (OLS). Metode OLS digunakan untuk mengetahui hubungan antara variabel dependen dengan variabel independen. Model regresi linier berganda sebagai berikut:

$$
L P=\beta_{0}+\beta_{1} J+\beta_{2} P+\beta_{3} K P+\beta_{4} S C+\beta_{5} L S+\beta_{5} u+e
$$

Keterangan/Remarks: :

LP : Pendapatan (Rupiah dalam log)/Income tujuh hari terakhir (Rupiah in log term)

SC : Strategi coping $D=1$ melakukan, $D=0$ lainnya/ Coping Startegy $D=1$ conduct Stategy coping; $D=0$ other

$\mathrm{J}$ : Jarak melaut $(\mathrm{km}) /$ Distance $(\mathrm{km})$

$\mathrm{P} \quad$ : Pengalaman (tahun)/Working experience (year)

KP : Kepemilian perahu ( $D=1$ memiliki; $D=0$ other $) /$ Boat ownership has $D=1$ has boat, $D=0$ other)

LS : Lama sekolah (tahun)/enrolment (year)

$\cup \quad$ : Usia nelayan (tahun)/age (year)

Koefisien/Coefficient $\beta_{2}, \beta_{3}, \beta_{5}, \beta_{6}>0, \beta_{1}, \beta_{4} \neq 0$

Hasil estimasi akan diuji asumsi klasik, meliputi normalitas, murlikolinearitas dan heteroskedastisitas. Pengujian normalitas menggunakan uji Jarque Berra. Untuk pengujian multikolinearitas menggunakan nilai VIF. Adapun untuk pengujian heteroskedastisitas menggunakan uji White. Selanjutnya akan diuji apriori ekonomi dan uji statistik sebelum melakukan pembahasan hasil estimasi.

\section{HASIL DAN PEMBAHASAN}

\section{Deskripsi Karakteristik Responden}

Karakteristik nelayan berdasarkan usia, pendidikan terakhir, pekerjaan utama, pengalaman melaut dan pendapatan disajikan di Tabel 2 . Usia nelayan dikedua lokasi memiliki perbedaan kelompok usia, di Kabupaten Bantul proporsi usia lebih merata di setiap kelompok, yaitu sekitar 28,1 sampai 35,9\%. Kondisi berbeda ditunjukkan oleh nelayan di Kabupaten Gunungkidul, dimana usia nelayan didominasi usia 36-50 tahun yaitu sekitar 60,0\%, selanjutnya kelompok usia 20-35 sebesar 34,3\% Temuan ini menunjukkan usia di Kabupaten Gunungkidul didominasi oleh kelompok usia muda. Untuk pendidikan terakhir nelayan juga menunjukkan perbedaan di kedua kabupaten. Di Kabupaten Bantul pendidikan nelayan lebih merata dari Sekolah Dasar (SD), Sekolah Menengah Pertama (SMP)dan Sekolah Menegah Atas (SMA). Adapun di Kabupaten Gunungkidul mayoritas $60,0 \%$ lulusan SMP, selebihnya SD $(20,0 \%)$ dan SMA $(17,1 \%)$.

Untuk kepemilikan perahu juga menunjukkan keadan yang hampir sama Tabel 2 juga menyajikan pengalaman melaut nelayan di kedua kabupaten yang menunjukkan keadaan yang hampir sama yaitu didominasi oleh nelayan dengan pengalaman kurang dari 15 tahun dan 16-30 tahun, dan 
Tabel 2. Karakteristik Nelayan di Bantul dan Gunungkidul, 2019.

Table 2. Marine Fisher's Characteristic in Bantul and Gunungkidul, 2019.

\begin{tabular}{|c|c|c|c|c|}
\hline \multirow[b]{2}{*}{ Katagori/Catagory } & \multicolumn{2}{|c|}{ Bantul } & \multicolumn{2}{|c|}{ Gunungkidul } \\
\hline & $\begin{array}{l}\text { Frekuensi/ } \\
\text { Frequency }\end{array}$ & $\begin{array}{l}\text { Persentase/ } \\
\text { Percentage }\end{array}$ & $\begin{array}{l}\text { Frekuensi/ } \\
\text { Frequency }\end{array}$ & $\begin{array}{l}\text { Persentase/ } \\
\text { Percentage }\end{array}$ \\
\hline \multicolumn{5}{|l|}{ Usia (Tahun)/Age (Year) } \\
\hline $20-35$ & 23 & 35.9 & 12 & 34.3 \\
\hline $36-50$ & 23 & 35.9 & 21 & 60.0 \\
\hline $51-65$ & 18 & 28.1 & 2 & 5.7 \\
\hline \multicolumn{5}{|l|}{ Pendidikan/Education } \\
\hline$<$ SD/Less elementary & 1 & 1.6 & 1 & 2.9 \\
\hline Sekolah Dasar/Elementary & 22 & 34.4 & 7 & 20.0 \\
\hline $\begin{array}{l}\text { Sekolah Menengah pertama/ } \\
\text { Junior High }\end{array}$ & 17 & 26.6 & 21 & 60.0 \\
\hline $\begin{array}{l}\text { Sekolah Menengah Atas/ } \\
\text { Senior High }\end{array}$ & 22 & 34.4 & 6 & 17.1 \\
\hline $\begin{array}{l}\text { Perguruan Tinggi/ } \\
\text { Undergraduate }\end{array}$ & 1 & 1.6 & 0 & 0.0 \\
\hline \multicolumn{5}{|l|}{ Pengalaman Melaut } \\
\hline$<15$ & 30 & 46.9 & 13 & 37.1 \\
\hline $16-30$ & 28 & 43.8 & 17 & 48.6 \\
\hline $31-45$ & 6 & 9.4 & 5 & 14.3 \\
\hline \multicolumn{5}{|c|}{ Kepemilikan Perahu/ Boat Ownership } \\
\hline Memiliki Perahu/Has boat & 36 & 56.3 & 21 & 60.0 \\
\hline $\begin{array}{l}\text { Tidak Memiliki Perahu/ } \\
\text { Has not boat }\end{array}$ & 28 & 43.8 & 14 & 40.0 \\
\hline
\end{tabular}

pengalaman paling lama adalah 31-45 tahun. Hal ini sesuai dengan studi Suadi (2001) yang menyatakan mata pencaharian nelayan bagi masyarakat pesisir Selatan DIY berkembang pada akhir tahun 1970-an. Dengan kata lain berkembang sekitar 50 tahun-an yang lalu, sehingga sesuai dengan temuan pengalaman terlama sekitar 45 tahun. Untuk kepemilikan perahu menunjukkan sekitar 53,6-60,0\% nelayan memiliki perahu.

\section{Pendapatan}

Pendapatan nelayan terbagi menjadi dua, yaitu pendapatan dari mata pencaharian nelayan dan mata pencaharian dari pekerjaan sampingan. Tabel 3 menyajikan pendapatan dalam tujuh hari terakhir dari kedua sumber pencaharian tersebut. Pendapatan yang bersumber dari nelayan didominasi oleh pendapatan kurang dari Rp1.500.00,00 sebesar $75,8 \%$, lebih rendah dibandingkan dengan pendapatan dari pekerjaan sampingan, yaitu $85,5 \%$.

Tabel 3. Kisaran Pendapatan Nelayan Berdasarkan Sumber Pekerjaan di Bantul dan Gunungkidul Tahun 2019.

Table 3. Fishers Income Range Based Employment Resources in Bantul and Gunungkidul, 2019.

Katagori/ Catagory Frekuensi/Frequency

\section{Persentase (\%)/ Percentage (\%)}

Pendapatan Nelayan (Rupiah) tujuh hari terakhir/ Fisher's Income (Idr)

$\begin{array}{lrr}<1,500,000 & 75 & 75.8 \\ 1,500,001-3,000,000 & 16 & 16.2 \\ 3,000,001-4,500,000 & 3 & 3.0 \\ >4,500,000 & 5 & 5.1\end{array}$

Pendapatan Lainnya (Rupiah) tujuh hari terakhir /Other Income (Rupiah)

$\begin{array}{lrr}<1,500,000 & 53 & 85.5 \\ 1,500,001-3,000,000 & 5 & 8.1 \\ 3,000,001-4,500,000 & 0 & 0.0 \\ >4,500,000 & 4 & 6.5\end{array}$


Kelompok kedua disusul pendapatan dengan kisaran Rp1.500.001-Rp3.000.000, sebesar 16,2\%, sedangkan pendapatan dari pekerjaan sampingan $8,1 \%$. Artinya pendapatan dari utama relatif lebih tinggi dibandingkan dengan pekerjaan sampingan nelayan.

\section{Strategi Coping Nelayan}

Ketika nelayan tidak melaut, para nelayan melakukan berbagai upaya agar tetap memperoleh pendapatan untuk mempertahan kan perekonomian. Tabel 4 menyajikan jumlah strategi coping yang dilakukan nelayan. Untuk itu nelayan melakukan adaptasi dengan melakukan beberapa penyesuaian. Mekanisme tersebut disebut sebagai strategi coping.Berdasarkan hasil survei terdapat gambaran yang hampir sama di kedua kabupaten, dimana hampir seluruh nelayan melakukan strategi coping yaitu sebanyak 96,7\%, di Kabupaten Bantul, bahkan di Kabupaten Gunungkidul semua nelayan melakukan strategi coping. Tabel 4 juga menunjukan berapa banyak strategi yang dilakukan nelayan. Para nelayan telah berusaha keras untuk mempertahankan nafkahnya. Nelayan melakukan strategi coping mulai dari satu sampai tujuh strategi. Di Kabupaten Bantul strategi yang paling dilakukan sebanyak tiga dan empat strategi, sedangkan diKabupaten Gunungkidul lebih merata, namun paling bayak empat strategi. Namun nelayan di Kabupaten Gunungkidul lebih banyak melakukan strategi coping yaitu tujuh strategi, sedangkan Kabupaten Bantul lima strategi.

Banyaknya strategi yang dipilih ini bisa menunjukkan bahwa nelayan berusaha sangat keras untuk mempertahankan strategi nafkahnya saat tidak bisa melaut. Meskipun yang memilih untuk melakukan satu strategi juga cukup banyak yaitu dilakukan oleh 19 nelayan di kedua kabupaten namun, selebihnya memilih untuk melakukan lebih dari satu strategi
Berdasarkan hasil survei, menunjukkan bahwa nelayan menggunakan strategi yang beragam. Secara garis besar terdapat tiga strategi besar yang dipilih oleh nelayan, yaitu strategi pasif, strategi aktif dan strategi jaringan. Pembagian ini didasarkan pada Syuryani (2017). Strategi pasif yaitu mengurangi pengeluran rumah tangga. Strategi aktif yaitu strategi mengoptimalkan potensi keluarga. Adapun strategi jaringan menunjukkan strategi dengan menjalin relasi formal maupun informal di lingkungan sosialnya dan lingkungan kelembagaan. Bentuk strateginya bisa berupa meminjam uang tetangga atau ke rentenir, tengkulak, koperasi, finance atau bank, selain itu juga bisa dengan menghutang di warung.

Tabel 5 menyajikan strategi coping yang dipilih oleh rumah tangga saat tidak melaut. Pilihan strategi coping pasif di kedua kabupaten menunjukkan temuan hampir sama dimana nelayan berupaya untuk menghemat pengeluaran kemudian mengkonsumsi makanan yang lebih terjangkau. Adapun untuk strategi aktif yang dipilih nelayan didominasi oleh mencari pekerjaan lain. Namun untuk strategi aktif lainnya menunjukan temuan yang berbeda, dimana menjual aset (emas dan ternak) presentasenya lebih tinggi di Kabupaten Gunungkidul. Untuk strategi aktif lainnya adalah migrasi dan meminta anak-anak untuk bekerja. Untuk strategi jaringan, nelayan memilih untuk meminjam uang baik kepada kerabat dan lembaga keuangan, dimana meminjam ke kerabat lebih banyak dipilih oleh nelayan di Kabupaten Gunungkidul. Berdasarkan hasil tersebut maka strategi yang paling banyak dilakukan oleh nelayan adalah mencari pekerjaan lain dan menghemat pengeluaran, sedangkan yang paling jarang dilakukan adalah meminta anak-anak untuk ikut bekerja. Temuan ini menunjukkan nelayan telah melakukan ketiga strategi baik pasif, aktif maupun jaringan.

Tabel 4. Strategi Coping yang Dilakukan Nelayan Bantul dan Gunungkidul, 2019.

Table 4. Coping Strategy which Fisherman's Did in Bantul and Gunungkidul, 2019.

\begin{tabular}{lcccc}
\hline \multirow{2}{*}{$\begin{array}{c}\text { Strategi Copingl } \\
\text { Coping Strategy }\end{array}$} & \multicolumn{2}{c}{ Bantul } & \multicolumn{2}{c}{ Gunungkidul } \\
\cline { 2 - 5 } & $\begin{array}{c}\text { Frekuensi/ } \\
\text { Frequency }\end{array}$ & $\begin{array}{c}\text { Persentase/ } \\
\text { Percentage (\%) }\end{array}$ & $\begin{array}{c}\text { Frekuensi/ } \\
\text { Frequency }\end{array}$ & $\begin{array}{c}\text { Persentase/ } \\
\text { Percentage (\%) }\end{array}$ \\
\hline Tidak melakukan koping/Not coping & 2 & 3.1 & 0 & 0.0 \\
Satu strategi/One strategy & 14 & 21.9 & 5 & 14.3 \\
Dua strategi/Two strategy & 11 & 17.2 & 6 & 17.1 \\
Tiga strategi/Three strategy & 14 & 21.9 & 6 & 17.1 \\
Empat strategi/Four strategy & 15 & 23.4 & 7 & 20.0 \\
Lima strategi/Five strategy & 8 & 12.5 & 4 & 11.4 \\
Enam strategi/Six strategy & 0 & 0.0 & 5 & 14.3 \\
Tujuh strategi/Seven strategy & 0 & 0.0 & 2 & 5.7 \\
\hline
\end{tabular}


Tabel 5. Strategi Coping yang Dilakukan Nelayan.

Table 5. Coping Strategy which Fishers Did.

\begin{tabular}{|c|c|c|c|c|}
\hline \multirow[b]{2}{*}{ Strategi Coping/Coping Strategy } & \multicolumn{2}{|c|}{ Bantul } & \multicolumn{2}{|c|}{ Gunungkidul } \\
\hline & $\begin{array}{l}\text { Frekuensi/ } \\
\text { Frequency }\end{array}$ & $\begin{array}{c}\text { Persentase/ } \\
\text { Percentage (\%) }\end{array}$ & $\begin{array}{l}\text { Frekuensi/ } \\
\text { Frequency }\end{array}$ & $\begin{array}{c}\text { Persentasel } \\
\text { Percentage (\%) }\end{array}$ \\
\hline \multicolumn{5}{|l|}{ Strategi Pasif IPassive Strategy } \\
\hline Menghemat pengeluaran/Reduce Expenditure & 46 & 71.9 & 26 & 74.3 \\
\hline $\begin{array}{l}\text { Mengkonsumsi makanan terjangkau/ } \\
\text { Consume affordable food }\end{array}$ & 29 & 45.3 & 16 & 45.7 \\
\hline \multicolumn{5}{|l|}{ Strategi Aktif/ Active Strategy } \\
\hline Menjual terna/Sell Livestock & 8 & 12.5 & 15 & 42.9 \\
\hline Menjual aset (emas)/Sale Asset (Gold) & 10 & 15.6 & 12 & 34.3 \\
\hline Mencari pekerjaan lain/Looking another job & 44 & 68.8 & 30 & 85.7 \\
\hline Migrasi/Migration & 5 & 7.8 & 5 & 14.3 \\
\hline $\begin{array}{l}\text { Anak-anak untuk ikut bekerja/ } \\
\text { Working children }\end{array}$ & 5 & 7.8 & 2 & 5.7 \\
\hline \multicolumn{5}{|l|}{ Strategi Jaringan/Lingkage Strategy } \\
\hline $\begin{array}{l}\text { Meminjam uang kepada kerabat/ } \\
\text { Borrow from Relative }\end{array}$ & 15 & 23.4 & 15 & 42.9 \\
\hline $\begin{array}{l}\text { Meminjam uang ke lembaga keuangan/ Borrow } \\
\text { from finance Institution }\end{array}$ & 16 & 25.0 & 6 & 17.1 \\
\hline
\end{tabular}

Pemilihan strategi coping nelayan di Kabupaten Bantul dan Gunungkidul yang didominasi mencari pekerjaan lain. Temuan ini menekankan pada strategi coping dalam bentuk ekonomi. Seperti dinyatakan oleh Lailiyah et al. (2018) nelayan mencari pekerjaan sampingan dan ikut serta dalam kegiatan simpan pinjam koperasi serta arisan sesama nelayan. Mencari pekerjaan merupakan strategi coping yang sering digunakan oleh nelayan seperti yang ditunjukkan oleh studi Lailiyah et al. (2018), Yuliana, Widiono, \& Cahyadinata, (2016), Wibowo \& Satria (2015), Helmi \& Satria (2012), dan Widodo (2011). Adapun meminjam juga merupakan strategi yang banyak dipilih nelayan (Casmiwati et al., 2019; Syuryani, 2017; Yuliana et al., 2016; Helmi \& Satria, 2012; Widodo, 2011)

\section{Determinan Pendapatan Rumah Tangga Nelayan}

Uji normalitas dan heteroskedastisitas disajikan pada Tabel 6. Uji normalitas menggunakan uji Jarque -Berra. Uji normalitas bertujuan untuk mengetahui apakah nilai residual berdistribusi normal atau tidak normal. Pengujian normalitas Jarque Berra menunjukkan nilai 0,462118 dengan nilai probabiliti 0,793693 lebih besar dari 0,05. Hasil ini menunjukkan residual berdistribusi normal, dengan kata lain memenuhi asumsi normalitas.

Untuk mendeteksi variabel yang diteliti terjadi heterokedasitas atau tidak, salah satunya adalah melalui uji White. Keputusan dalam uji White adalah apabila nilai probabilitas chi square hitung lebih kecil dari nilai kesalahan. Menurut hasil olah data pada Tabel 6 dimana nilai probabilitas Chi-square 0,1059 lebih besar dari 0,05 maka dapat disimpulkan tidak terjadi heterokedasititas.

Tabel 6. Uji Multikolinearitas.

Table 6. Multicollinearity Test.

\begin{tabular}{lcc}
\hline \multicolumn{1}{c}{ Uji/Tests } & $\begin{array}{c}\text { Nilai Chi Squarel } \\
\text { Chi Square Value }\end{array}$ & $\begin{array}{c}\text { Probabilitias/ } \\
\text { Probablity }\end{array}$ \\
\hline $\begin{array}{l}\text { Uji Jarque Berra/ } \\
\text { Jarque Berra Test }\end{array}$ & 0.462118 & 0.793693 \\
\hline $\begin{array}{l}\text { Uji White/ } \\
\text { White Test }\end{array}$ & 10.47854 & 0.1059 \\
\hline
\end{tabular}

Pengujian asumsi selanjutnya adalah multikolinearitas, dimana pengujian menggunakan nilai Varian Inflation Factor (VIF). Jika nilai VIF lebih kecil dari 10.00 maka tidak terjadi multikolinearitas. Tabel 7 menyajikan nilai VIF dari model. Berdasarkan nilai VIF, semua variabel di bawah nilai 10 , artinya model terbebas dari multikolinearitas.

Tabel 7. Uji Multikolinearitas.

Table 7. Multicollinearity Test.

\begin{tabular}{lcc}
\hline \multicolumn{1}{c}{$\begin{array}{c}\text { Variabel/ } \\
\text { Variable }\end{array}$} & $\begin{array}{c}\text { Koefisien/ } \\
\text { Coefficient }\end{array}$ & VIF \\
\hline $\begin{array}{l}\text { Konstanta/Constant } \\
\text { Strategi Coping/ Coping }\end{array}$ & 0.422500 & NA \\
$\begin{array}{l}\text { Strategy } \\
\text { Jarak/Distance }\end{array}$ & 0.062570 & 1.060113 \\
$\begin{array}{l}\text { Pengalaman Melaut/ } \\
\text { Work Experince }\end{array}$ & $5.12 \mathrm{E}-06$ & 1.041004 \\
$\begin{array}{l}\text { Dummy Kepemilian perahu/ } \\
\text { Boat ownership dummy }\end{array}$ & 0.000232 & 1.822154 \\
$\begin{array}{l}\text { Lama sekolah /Enrolment } \\
\text { Usia/age }\end{array}$ & 0.059999 & 1.244252 \\
\hline
\end{tabular}


Tabel 8 menyajikan hasil estimasi regresi berganda pendapatan nelayan. Penjelasan dibagi menjadi 4 bagian, pertama pengujian asumsi klasik, uji apriori ekonomi, uji statistik, dan terakhir pembahasan hasil. Berdasarkan hasil estimasi, maka secara simultan nilai $\mathrm{F}$ hitung sebesar 3,192721 dengan probabilitas 0,105 atau $1,05 \%$ lebih kecil dari level of significant $5 \%$, sehingga keputusannya adalah menolak $\mathrm{H}_{0}$ artinya variasi perubahan pendapatan dapat dijelaskan oleh semua variabek independen. Untuk koefisien determinasi, nilai adjusted $R^{2}$ sebesar 0,100617 atau $10,06 \%$ variasi pendapatan nelayan mampu dijelaskan oleh variabel-variabel independen, sedangkan selebihnya dijelaskan oleh variabel lain di luar model.

Untuk pengaruh parsial masing-masing variabel independen, nilai $t$ tabel pada a $5 \%$ satu sisi adalah 1,645 , sedangkan untuk $\alpha / 2$ dua sisi yaitu 1,960. Berdasarkan hasil estimasi uji parsial variabel yang signifikan adalah kepemilikan strategi coping, perahu dan pengalaman, sedangkan variabel jarak, usia dan pendidikan tidak berpengaruh signifikan.

\section{Pengaruh Strategi Coping terhadap Pendapatan Nelayan}

Untuk variabel strategi coping, memiliki koefisien negatif dan signifikan tingkat kepercayaan $10 \%$. Hasil estimasi ini menunjukkan pendapatan nelayan justru lebih kecil jika dibandingan tidak melakukan strategi coping.Strategi coping dalam studi ini adalah mencari pekerjaan lain/sampingan. Temuan ini menunjukkan bahwa strategi coping mencari pekerjaan lain belum mampu meningkatkan pendapatan nelayan. Hal ini dikarenakan pendapatan dari pekerjaan lain tidak sebesar dari pendapatan sebagai nelayan.
Temuan pada Tabel 3 menunjukkan, bahwa pendapatan dari pekerjaan sampingan lebih kecil dibandingkan dengan pendapatan sebagai nelayan. Jadi meskipun strategi coping mencari pekerjaan lain menjadi pilihan nelayan seperti ditunjukkan Lailiyah et al. (2018), Yuliana, Widiono, \& Cahyadinata, (2016), Wibowo \& Satria (2015), Helmi \& Satria (2012), namun strategi tersebut belum mampu meningkatkan pendapatan. Subair, Kolopaking, Adiwibowo, \& Pranowo (2014) menunjukkan sistem nafkah akibat dampak perubahan iklim memiliki resiliensi yang yang terbatas, rapuh dan memiliki ambang batas.

\section{Pengaruh Jarak}

Untuk variabel jarak memiliki koefisien negatif, hal ini mengandung arti bahwa semakin jauh melaut akan menurunkan pendapatan, namun temuan ini tidak cukup nyata berpengaruh terhadap pendapatan nelayan. Kemungkinan hal ini disebabkan jarak yang jauh belum menjamin adanya tangkapan ikan yang banyak. Apalagi saat ini dengan adanya perubahan iklim menyebabkan beberapa dampak terhadap tangkapan ikan. Menurut Ulfa (2018) perubahan iklim menyebabkan jarak tempuh mencari ikan lebih jauh. Lebih lanjut menurut Dewiyanti et al. (2019) perubahan iklim menyebabkan berkurang nya produksi ikan, bertambahnya biaya melaut, kurang efektifnya alat tangkap digunakan dan sulitnya menentukan wilayah tangkap.

\section{Pengalaman Melaut}

Pengalaman melaut nelayan memiliki pengaruh positif terhadap pendapatan nelayan. Semakin berpengalaman seorang nelayan akan semakin memiliki keahlian dalam menangkap

Tabel 8. Hasil Estimasi Determinan Pendapatan Nelayan.

Table 8. Estimation Result of Fisher's Income Determinants.

\begin{tabular}{lccc}
\hline \multicolumn{1}{c}{ Variabel/ Variable } & $\begin{array}{c}\text { Koefisien/ } \\
\text { Coefficient }\end{array}$ & $\begin{array}{c}\text { t Hitung/ } \\
\text { t Value }\end{array}$ & $\begin{array}{c}\text { Probabilitas/ } \\
\text { Probability }\end{array}$ \\
\hline Konstanta/Constant & $14.00831^{* *}$ & 21.55125 & 0.0000 \\
Dummy Strategi Coping/Coping Startegi & $-0.475841^{* *}$ & -1.902296 & 0.0606 \\
Jarak/Distance & -0.002115 & -0.934569 & 0.3527 \\
Pengalaman Melaut/Work Experince & $0.026366^{* *}$ & 1.730352 & 0.0873 \\
Dummy Kepemilian perahu/boat & $0.487693^{*}$ & 1.991018 & 0.0498 \\
ownership dummy & 0.014379 & 0.428491 & 0.6694 \\
Lama sekolah /enrollment & -0.016412 & -1.162733 & 0.2483 \\
Usia/Age & 0.148247 & Nilai F/F Value & 2.407679 \\
\hline R-squared & 0.086674 & Prob & 0.034026 \\
Adjusted R-squared & & & \\
\hline
\end{tabular}


ikan yang akan mempengaruhi jumlah tangkapan ikan. Tangkapan ikan yang lebih banyak akan mempengaruhi pendapatan nelayan. Temuan ini konsisten dengan studi terdahulu (Rahim, 2011; Rahim, Retno, Hastuti, \& Pradipta, 2018; Ratna, Munanzar, Albra, \& Arifin, 2018; Wibowo et al., 2018) yang menunjukkan adanya pengaruh positif dari pengalaman melaut.

\section{Kepemilikan Perahu}

Kepemilikan perahu mempengaruhi pendapatan dan memiliki koefisien positif. Artinya variabel lain konstan, nelayan yang memiliki perahu memiliki pendapatan lebih besar dibanding dengan nelayan yang tidak memiliki perahu. Nelayan yang memiliki perahu sendiri memiliki keuntungan yang dibanding yang tidak memiliki perahu. Nelayan pemilik perahu cenderung memiliki pendapatan yang lebih besar, karena nelayan tidak perlu mengeluarkan uang sewa perahu. Selain itu nelayan yang memiliki perahu dapat memiliki pendapatan lain dari menyewakan perahu.

\section{Pendidikan}

Temuan sebelumnya menunjukkan bahwa pengalaman melaut berpengaruh positif terhadap pendapatan nelayan. Hal ini tidak sejalan dengan pendidikan nelayan berupa lama sekolah, meskipun memiliki koefisien positif namun tidak cukup nyata berpengaruh terhadap pendapatan nelayan. Lamanya pendidikan formal nelayan tidak mempengaruhi pendapatan.Hal ini dimungkinkan karena sebagai nelayan memerlukan skill yang berbeda, yaitu keterampilan bagaimana mencari ikan di laut, pengetahun iklim dan posisi dimana ikan berada. Keterampilan tersebut tidak diperoleh di pendidikan formal, namun melalui pengalaman yang telah ditempuh. Artinya pengalaman sebagai nelayan lebih memberikan pengaruh kepada pendapatan dibandingkan pendidikan formal. Temuan ini konsisten dengan studi Rahim et al. (2018) yang menemukan pendidikan nelayan tidak berpengaruh terhadap pendapatan.

\section{Usia Nelayan}

Variabel lain yang berkaitan dengan sumberdaya manusia nelayan yaitu usia, meskipun memiliki koefisien negatif yang artinya semakin bertambah usia maka pendapatan akan mengalami penurunan, namun tidak memiliki pengaruh secara nyata terhadap pendapatan nelayan. Usia tidak berpengaruh kepada pendapatan, hal ini dimungkinkan karena dalam mencari ikan baik segala usia bisa memperoleh ikan selama memiliki pengalaman melaut yang cukup. Usia dikaitkan dengan kemampuan fisik melaut. Meskipun usia semakin bertambah, secara fisik mengalami penurunan, namun dengan pengalaman yang baik tetap akan tetap mampu mempertahankan pendapatan, sehingga meskipun semakin bertambah usia tidak berpengaruh terhadap penurunan pendapatan.

\section{KESIMPULAN DAN REKOMENDASI KEBIJAKAN}

\section{Kesimpulan}

Nelayan di Kabupaten Bantul dan Gunungkidul hampir semua telah melakukan strategi coping, mulai dari satu sampai tujuh strategi. Secara garis besar terdapat tiga strategi besar yang dipilih oleh nelayan, yaitu strategi pasif, strategi aktif dan strategi jaringan. Strategi pasif menunjukkan nelayan berupaya untuk menghemat pengeluaran kemudian mengkonsumsi makanan yang lebih terjangkau. Strategi aktif yang didominasi oleh mencari pekerjaan lain, selain menjual aset, dan migrasi. Nelayan melakukan strategi jaringan dengan meminjam uang baik kepada kerabat dan lembaga keuangan.

Strategi coping berupa mencari pekerjaan lain/ sampingan belum mampu meningkatkan pendapatan nelayan. Pendapatan nelayan justru lebih kecil jika dibandingan tidak melakukan strategi coping. Hal ini dikarenakan pendapatan dari pekerjaan lain tidak sebesar dari pendapatan sebagai nelayan. Pendapatan nelayan dipengaruhi secara positif oleh pengalaman melaut dan kepemilikan perahu, sedangkan pendidikan nelayan, usia nelayan dan jarak tidak berpengaruh terhadap pendapatan nelayan.

\section{Rekomendasi Kebijakan}

Menilik pada hasil temuan di lapangan, bahwa kepemilikan perahu memberikan pengaruh terhadap pendapatan nelayan, maka pemerintah sebaiknya mempermudah kepemilikan perahu bagi nelayan. Kebijakan bisa berupa kredit terjangkau bagi kepemilikan perahu disertai dengan persyaratan lebih mudah. Jika nelayan belum mampu maka dapat mengoptimalkan kapasitas dari organisasi nelayan yang telah ada untuk memiliki perahu secara berkelompok. Adanya kredit kepemilikan perahu akan membantu melayan untuk memenuhi kebutuhan akan perahu. Kepemilikan perahu yang 
tangguh yang dapat digunakan dalam berbagai macam cuaca akan memberikan kesempatan kepada nelayan untuk lebih sering melaut dan memperoleh pendapatan.

Selain itu dengan berpengaruhnya pengalaman nelayan terhadap pendapatan, maka kebijakan yang bisa dilakukan dengan meningkatkan edukasi keterampilan bagi nelayan untuk mencari dan mengelola sumber daya ikan. Adanya pelatihan ketrampilan nelayan diharapakan dapat meningkatkan kemampuan nelayan semakin baik dalam memperoleh pendapatan.

\section{UCAPAN TERIMA KASIH}

Penulis mengucapkan terima kasih kepada LPPM Universitas Ahmad Dahlan yang telah memberikan dukungan dana penelitian. Selain itu penulis juga mengucapkan terimakasih kepada semua mahasiswa yang tergabung dalam Tim Enumerator sehingga penelitian ini dapat selesai dengan lancar terutama dalam pengumpulan dan tabulasi data primer.

\section{PERNYATAAN KONTRIBUSI PENULIS}

Dengan ini kami menyatakan bahwa kontribusi masing-masing penulis terhadap pembuatan karya tulis adalah: Dini Yuniarti sebagai kontributor utama dan Lestari Sukarniati sebagai anggota.

\section{DAFTAR PUSTAKA}

Akbar, T., \& Huda, M. (2017). Nelayan, lingkungan, dan perubahan iklim (studi terhadap kondisi sosial ekonomi pesisir di kabupaten malang). Wahana, 68(June), 27-38. http://jurnal.unipasby.ac.id/ index.php/whn/article/view/630/895

Badan Perencanaan Pembangunan Nasional. (2014). Peraturan Presiden Republik Indonesia Nomor 2 Tahun 2015 tentang Rencana Pembangunan Jangka Menengah Nasional (RPJMN) 2015-2019. https://peraturan.bpk.go.id/Home/Details/41718/ perpres-no-2-tahun-2015

Badan Pusat Statistik Indonesia. (2018). Statistik Sumber Daya Laut dan Pesisir. Badan Pusat Statistik. https://www.bps.go.id/publication/2018/12/07/93 a0fd8885fe2ac14201e71a/statistik-sumber-dayalaut-dan-pesisir-2018.html

Casmiwati, D., Ibrahim, A. Z. bin, \& Bakar, A. H. (2019). Strategy of fishermen surabaya city, indonesia to maintain their livelihood. European Journal of Research, 3(1998), 23-28. https://doi.org/http:// dx.doi.org/10.26739/2521-3253-2019-3-4
Creswell, J. (2013). Qualitative, quantitative, and mixed methods approaches. Research Design, 1-26. https://doi.org/10.2307/3152153.

Dewiyanti, S., Ma'ruf, A., \& Indriyani, L. (2019). Adaptasi nelayan Bajau terhadap dampak perubahan iklim di Pesisir Soropia Kabupaten Konawe, Sulawesi Tenggara. Ecogreen, 5 (1), 23-29. http://ojs.uho. ac.id/index.php/green/article/view/4796

Helmi, A., \& Satria, A. (2012). Fisher's Adaptation Strategies to Ecological Changes Abstract. Makara, Sosial Humaniora, 16(1), 68-78. http:// www.ijil.ui.ac.id/index.php/humanities/article/ viewFile/1494/1296

Imron, M. (2003). Kemiskinan dalam masyarakat nelayan. Jurnal Masyarakat dan Budaya, 5(1), 63-82. https://jmb.lipi.go.id/

Lailiyah, A., Juhadi, \& Tjahyono, H. (2018). Geo Image ( Spatial-Ecological-Regional ) Strategi Coping Nelayan Terhadap Perubahan Iklim Studi, Pada Masyarakat. Geo Image (Spatial-Ecological-Regional), 7(1), 47-53. http://journal.unnes. ac.id/sju/index.php/geoimage

Maryam, S. (2017). Strategi Coping: Teori Dan Sumberdayanya. Jurnal Konseling Andi Matappa, 1, 101-107. https://journal.stkip-andi-matappa. ac.id/jurkam/article/view/12

Patriana, R., \& Satria, A. (2013). Pola Adaptasi Nelayan Terhadap Perubahan Iklim : Studi Kasus Nelayan Dusun Ciawitali, Desa Pamotan, Kecamatan Kalipucang, Kabupaten Ciamis, Jawa Barat Adaptation Pattern of Fishers In Addressing Climate Change: A Case Study Of Fishers In Ciawitali. Jurnal Sosial Ekonomi Kelautan Dan Perikanan, 8(1), 11-23. http://ejournal-balitbang. kkp.go.id/index.php/sosek/article/view/1191

Prihatin, R. B. (2017). Strategi Nafkah Keluarga Nelayan Miskin Perkotaan: Studi Di Cilacap Jawa Tengah Dan Badung Bali ( Urban Poor Fishing Families ' Livelihoods Strategies: Study In Cilacap Central Java And Badung Bali ) Rohani Budi Prihatin. Aspirasi, 8(2), 133-144. https://jurnal.dpr.go.id/ index.php/aspirasi/article/view/1261

Rahim, A. (2011). Analisis Pendapatan Usaha Tangkap Nelayan Dan Faktor-Faktor yang Mempengaruhinya Di Wilayah Pesisir Pantai Sulawesi Selatan. Jurnal Sosial Ekonomi Kelautan Dan Perikanan, 6(2). http://ejournal-balitbang.kkp. go.id/index.php/sosek/article/view/5776

Rahim, A., Retno, D., Hastuti, D., \& Pradipta, D. (2018). The Influence of Respondent Characteristics and Different Areas on Small-Scale Fisherman Household Income of Urban Coastal Areas in Pare-Pare City, South Sulawesi. Journal of Socioeconomics and Development, 1(2), 63-71. https:// doi.org/10.31328/jsed.v1i2.733

Ratna, Munanzar, Albra, W., \& Arifin, A. H. (2018). Determinant Income Of Fisherman's Of West Center Of Indonesia. Journal of Entrepre- 
neurship Education, 21(3), 1-7. https://www. abacademies.org/articles/Determinant-income-of-fishermans-of-west-center-of-indonesia-1528-2651-21-3-200.pdf

Retnowati, E. (2011). Nelayan Indonesia Dalam Pusaran Kemiskinan Struktural. Perspektif, XVI(3), 149-159. http://jurnal-perspektif.org/index.php/ perspektif/article/view/79

Setiawan, H. (2016). Strategi Coping Masyarakat Pulau Kecil Dalam Menghadapi Dampak Perubahan Iklim. Prosiding Seminar Nasional Geografi UMS, 288-298. https://publikasiilmiah.ums.ac.id/ handle/11617/10967

Suadi. (2001). Dari Petani Menjadi Nelayan: Kajian Historis Perikanan tangkap Pantai Selatan Yogyakarta. Jurnal Perikanan UMG, IV(1), 5-12. https://jurnal.ugm.ac.id/jfs/article/view/8869

Subair, Kolopaking, L. M., Adiwibowo, S., \& Pranowo, B. (2014). Resiliensi Komunitas Dalam Merespon Perubahan Iklim Melalui Strategi Nafkah ( Studi Kasus Desa Nelayan di Pulau Ambon Maluku ) Communities ' Resilience in Responding Climate Change through Livelihood Strategy: A Case Study in Fisher' s Village in Ambon. Jurnal Sosial Ekonomi Kelautan Dan Perikanan, 9(1), 77-90. http://ejournal-balitbang.kkp.go.id/index. php/sosek/article/view/1186/1097

Syuryani. (2017). Strategi Bertahan Hidup Rumah Tangga Nelayan Tradisional Dalam Mengatasi Kemiskinan. Jom FISIP, 4(2), 1-15. https://jom. unri.ac.id/index.php/JOMFSIP

Ulfa, M. (2018). Persepsi Masyarakat Nelayan Dalam Menghadapi Perubahan Iklim ( Ditinjau Dalam Aspek Sosial Ekonomi ). Jurnal Pendidikan Geografi, 23(1 Januari), 41-49. http://journal2. um.ac.id/index.php/jpg/article/view/2441

Wibowo, A., \& Satria, A. (2015). Strategi Adaptasi Nelayan di Pulau-Pulau Kecil terhadap Dampak Perubahan Iklim ( Kasus : Desa Pulau Panjang , Kecamatan Subi , Kabupaten Natuna, Kepulauan Riau ). Sodality: Jurnal Sosiologi Pedesaan, Agustus, 107-124. https://doi.org/10.22500/ sodality.v3i2.11336

Wibowo, B. A., Triarso, I., \& Suroyya, A. N. (2018). Tingkat Pendapatan Nelayan Gill Net Di Pelabuhan Perikanan Pantai Morodemak. Jurnal Perikanan Tangkap, 2(3), 29-36. https://ejournal2.undip. ac.id/index.php/juperta/article/view/3750

Widodo, S. (2011). Strategi Nafkah Berkelanjutan Bagi Rumah Tangga Miskin Di Daerah Pesisir Slamet/ Strategies of Sustainable Livelihood for Poor Household in Coastal Area. Makara, Sosial Humaniora, 15(1), 10-20. http://hubsasia.ui.ac. id/article/view/205
Yuliana, L., Widiono, S., \& Cahyadinata, I. (2016). Strategi Nafkah Rumah Tangga Nelayan Tradisional Dan Modern Pada Komunitas Nelayan Sekunyit, Kaur, Provinsi Bengkulu/Livelihood Strategy of Traditional and Modern Fisheries Household in Sekunyit Fishermen Community, Kaur Bengkulu Province. AGRISEP, 15(2 September), 163-175. https://ejournal.unib.ac.id/index.php/agrisep/ article/view/1181

Zamroni, A., \& Yamao, M. (2011). Sustainable Household Economics: A Case of Altering Income of Small-Scale Fishermen in Indonesia. 2011 International Conference on Financial Management and Economics, 11, 343-347. http://www.ipedr.com/vol11/66-W10042.pdf 